\title{
PELAKSANAAN KOMUNIKASI INTERNAL DALAM KETERLIBATAN KARYAWAN DI SOHO SQUARE INDONESIA
}

\author{
Luh Ketut Sri Laksmi ${ }^{1}$ \& Gracia Rachmi Adiarsi ${ }^{2}$ \\ STIKOM London School of Public Relations Jakarta
}

\begin{abstract}
This research discusses the activity of internal communication between Superior and Subordinate implemented by the Account Director in engaging subordinates Soho Square Indonesia to work on work and company. The purpose of this research is to understand the implementation and effect in the internal communication activities between superiors and subordinates in employee engagement at Soho Square Indonesia. The method used in this study is descriptive qualitative research method with primary and secondary data collection techniques in the form of semi structured interview with the resource person from Soho Square Indonesia. The analysis of qualitative data uses Miles and Huberman models comprising data collection, data reduction, data display and conclusion. Based on the results of the research, it was found out that the activity of internal communication between the superior and the subordinate in Soho Square Indonesia runs effectively to give impact in engaging the work of subordinates at Soho Square Indonesia.
\end{abstract}

\section{Keywords : Internal Communications, Employee Engagement, Leadership Style}

\begin{abstract}
ABSTRAK
Penelitian ini membahas tentang implementasi kegiatan komunikasi organisasi internal vertikal antara atasan dan karyawan dalam melibatkan karyawan di Soho Sqaure Indonesia dalam pekerjaan dan perusahaan. Tujuan dari penelitian ini untuk dapat memahami implementasi dan efek dari komunikasi internal antara atasan dan karyawan dalam keterlibatan karyawan di Soho Square Indonesia. Metode yang digunakan dalam penelitian ini adalah metode penelitian deskriptif kualitatif dengan teknik pengumpulan data primer dan sekunder berupa wawancara semi terstruktur dengan informan internal dari Soho Square Indonesia. Analisis data secara kualitatif dilakukan menggunakan model Miles dan Huberman yang terdiri dari koleksi data, penyederhanan data, penyajian data, dan pengambilan kesimpulan. Berdasarkan hasil penelitian, maka diketahui bahwa kegiatan komunikasi internal di Soho Square Indonesia berjalan efektif memberikan pengaruh dalam keterlibatan karyawan di Soho Square Indonesia.
\end{abstract}

Kata kunci : Komunikasi Internal, Keterlibatan Karyawan, Gaya Kepemimpinan

\footnotetext{
${ }^{1}$ Luh Ketut Sri Laksmi S.Ikom. email:luhketutsriaksmi@gmail.com

${ }^{2}$ Dra. Gracia Rachmi Adiarsi, MM. email: graciarachmi@gmail.com
} 


\section{PENDAHULUAN}

Periklanan merupakan suatu
cara bagi perusahaan untuk menyampaikan ataupun mempromosikan ide, produk ataupun jasa kepada target masyarakat. Penggunaan jasa agensi periklanan memperlihatkan perkembangan yang cukup pesat dilihat antara lain dari tayangan iklan yang hadir di berbagai media cetak dan media elektronik.

Berdasarkan laporan total belanja iklan di Indonesia yang dilakukan oleh Nielsen Advertising Information Service Indonesia pada akhir tahun 2016, terdapat pertumbuhan sebesar 14 persen belanja iklan di Indonesia yang sebelumnya sebesar Rp. 118 trilun (2015) menjadi Rp. 134,8 trilyun (2016). Hal ini disebabkan berbagai pelaku industri antara lain produk makanan dan minuman, produk kesehatan dan kecantikan, bahkan pemerintahan serta organisasi politik berkontribusi dalam meningkatkan pertumbuhan belanja iklan di Indonesia. Media televisi sebagai media terbesar penyumbang dalam belanja iklan sebesar 77 persen atau Rp. 103,8 trilyun (Lubis, 2017).

Soho Square Advertising \& Marketing Communication Agency merupakan salah satu penyedia jasa periklanan dan komunikasi pemasaran berskala internasional berasal dari New York, Amerika yang sekaligus berada di bawah naungan Wire and Plastic Products (WPP). Di Indonesia, Soho Square berada dalam Ogilvy Group Indonesia. Perusahaan ini pernah meraih penghargaan sebagai Indonesia Creative Agency of The Year pada tahun 2016. Penghargaan tersebut diadakan setiap tahun oleh Campaign Asia-Pacific Agency of the Year Awards (Adila Rahmanti, wawancara pra-riset, 8 September 2017).

Perusahaan Soho Square memiliki 30 karyawan yang di dalamnya termasuk tim Account Executive dengan tugas antara Abstract lain menangani komunikasi tim internal dengan klien-klien perusahaan. Dalam pelaksanaan tugas, personel Account Executive melakukan komunikasi internal terhadap tim account dan tim kreatif.

Soho Square melaksanakan pekerjaan komunikasi pemasaran termasuk pengembangan merek, perencanaan strategis, leading creative, interaksi merek, identitas merek dan penggunaan kemampuan media secara luas untuk merek klien yang menangani beberapa merek besar lokal maupun merek multinasional yang terdapat di Indonesia serta sejumlah industri di luar Indonesia melalui kerja sama dengan franchise yang terletak di Asia Pasifik (Adila Rahmanti, wawancara pra-riset, 8 September 2017). 
Penggunaan komunikasi internal atau komunikasi staf atau hubungan karyawan (Smith \& Mounter, 2005: 7) merupakan cara dalam mewujudkan sebuah kelompok dengan kinerja yang efektif, tiap-tiap individu di dalam sebuah organisasi memerlukan pemahaman terkait dengan tujuan serta arah apa yang akan diambil oleh organisasi kedepan, terlebih dengan dinamika agensi periklanan dan tuntutan deadline oleh klien membuat komunikasi internal menjadi esensial dalam membangun keterlibatan karyawan demi keberlangsungan dan kesuksesan perusahaan (Gills, 2006: 6).

Berdasarkan penjelasan di atas maka seperti apa gambaran proses pelaksanaan komunikasi internal oleh tim Account Executive di Soho Square Indonesia dalam menjalankan tugas dengan tim Account dan karyawan lainnya di perusahaan menjadi suatu hal yang menarik untuk diteliti. Oleh sebab itu peneliti ingin melihat bagaimana Pelaksanaan Komunikasi Internal dalam Keterlibatan Karyawan di Soho Square Indonesia.

Komunikasi internal (internal communication) merupakan interaksi atau pertukaran pesan serta informasi yang dilakukan oleh individu dalam sebuah organisasi atau lingkup yang sama. Lawrence D. Brennan (dalam Ruliana, dkk, 2018: 260) mendefinisikan komunikasi internal sebagai,

"Interchange of ideas among the administrators and its particular structure (organization) and interchange of ideas horizontally and vertically within the firm which gets work done (operation and management)." Pertukaran ide atau gagasan antara administrator dengan karyawan terjadi dalam sebuah organisasi, baik secara horizontal ataupun vertikal yang dapat menghasilkan berlangsungya kinerja operasional karyawan.

Bove'e dan Thill juga berpendapat sama dengan Lawrence, bahwa komunikasi internal adalah pertukaran informasi dan gagasan didalam organisasi. Hargie dan Tourish menyatakan bahwa komunikasi internal semakin diakui karena peranannya sebagai faktor penting penentu kesuksesan organisasi (Kalla, 2005: 304) .

Komunikasi internal memiliki keterkaitan yang erat dengan keberlangsungan organisasi sebagai kunci sukses pencapaian tujuan organisasi. dalam mewujudkan sebuah kelompok dengan kinerjanya yang efektif. Setiap individu di dalam sebuah organisasi memerlukan pemahaman terkait dengan visi dan misi organisasi, pencapaian dan 
tujuan serta arah apa yang akan diambil oleh organisasi kedepan (Gills, 2006: 6).

Keberhasilan

sebuah

perusahaan atas pencapaian yang kemudian menghasilkan pengakuan publik tidak terlepas dari andil masing-masing individu dalam perusahaan saat menjalankan tugastugasnya. Komunikasi sebagai cara dalam mendorong khalayaknya untuk ikut di dalamnya dan memberikan perhatian yang sama terhadap informasi atau pesan yang dibawakan oleh pembicara. Alison Theaker menyatakan fondasi yang kuat sebuah komunikasi antara karyawan dapat membangun kinerja yang termotivasi dan produktif selain itu komunikasi yang baik dapat menghasilkan customer branding yang berbeda dari yang lain (Theaker, 2004: 164).

Bruce Berger menjelaskan bahwa komunikasi internal sebagai employeelorganizational

communication adalah hal yang penting karena secara fundamental sebuah hubungan tumbuh dengan adanya komunikasi, dan berfungsinya sekaligus kelangsungan hidup sebuah perusahaan adalah berdasarkan dengan keefektivitasan hubungan pada tiap-tiap individu dan kelompok di dalamnya (Berger, 2008).

Menurut Berger (2008) untuk dapat terjadi komunikasi internal yang efektif bagi organisasi atau perusahaan diperlukan hubungan yang efektif antara individu di setiap level agar perusahaan dapat berfungsi secara maksimal. Oleh karena itu Berger membuat prinsipprinsip efektif komunikasi internal di perusahaan yaitu komunikasi dengan karyawan terjadi dengan menyesuaikan terhadap ketepatan waktu dan konten (timeliness and content), saluran (channel), peran kepemimpinan (leadership roles), partisipasi dan pengakuan (participation and recognition), pengukuran (measurement), budaya (culture).

Dalam menjalankan kegiatan usahanya, suatu organisasi tidak dapat terlepas dari keterlibatan karyawan (employee engagement). Istilah keterlibatan karyawan dapat diartikan berbeda-beda dalam sebuah organisasi. William A Kahn, seorang profesor dari Organizational Behaviour di Universitas Boston, Amerika yang merupakan bapak penemu 'keterlibatan' yang terkait dengan pekerjaan, menggambarkan keterlibatan karyawan yakni yang terlibat secara fisik, kognitif dan emosional sepenuhnya terkait dengan pekerjaan mereka.

Pengertian yang terbaru oleh Macey, W.H, dkk (Mackey et al, 2009) yang mendeskripsikan keterlibatan karyawan sebagai "perasaan individu pada tujuan dan fokus energinya, bukti kepada orang lain dalam memperlihatkan inisiatif 
individu, kemampuan beradaptasi, usaha dan persistensinya yang ditujukan kepada objektif organisasi. Sedangkan Schaufeli et al. (2002) mendefinisikan sebagai "keadaan pikiran positif, memuaskan, terkait dengan pekerjaan" (Albrecht, 2010: 75).

Keterlibatan karyawan di anggap sebagai elemen esensial dalam kesuksesan sebuah perusahaan karena dengan adanya keterlibatan para individu di dalam perusahaan, maka terbentuk komitmen secara emosional para karyawan terhadap tujuan perusahaan (Kruse, 2012). Menurut Kevin Kruse dalam artikel yang dimuat dalam Forbes.com (2012) pengertian komitmen emosional karyawan adalah sebagai berikut:

"This emotional commitment means engaged employees actually care about their work and their company. They don't work just for a paycheck, or just for the next promotion, but work on behalf of the organization's goals". Dimana berarti keterlibatan karyawan terdapat pada individu apabila perasaan peduli karyawan dengan pekerjaan sekaligus perusahaan saling terlibat, tidak hanya mementingkan gaji, promosi namun bekerja demi mencapai tujuan perusahaan.

Penelitian yang dilakukan Gallup pada tahun 2012 mengenai keterikatan keterlibatan karyawan dengan performa manajemen perusahaan kepada 1,4 juta pekerja dari 49 industri berbeda di 34 negara menyimpulkan bahwa hasil penelitian membuktikan keterlibatan karyawan mempengaruhi performa kerja karyawan dan perusahaan dengan 21 persen lebih tinggi produktivitas dan 22 persen lebih tinggi profitabilitas perusahaan (Gallup, 2013). Karyawan yang memiliki keterlibatan terhadap pekerjaan dan perusahaannya di gambarkan dengan individu yang memiliki dedikasi, entusias, rasa bangga, bertekad, inisiatif, fleksibel, gigih, energik, menemukan waktunya berlalu di tempat kerja dan leluasa menginvestasi usahanya dalam bekerja demi kepentingan bersama (Optimum Consulting, 2016).

Pendorong utama setelah pekerjaan yang bernilai tinggi (meaningful work) keterlibatan karyawan ditunjukan dalam laporan Gallup tahun 2008, 2010 dan 2012 (dalam O'Nelll, et al, 2015: 4) yakni dorongan dari atasan dapat berupa pengakuan, pujian atau masukan (feedback) kepada karyawan.

Penjelasan di atas mengartikan bahwa keterlibatan karyawan adalah keadaan dalam diri seseorang yang berperan sebagai karyawan dalam sebuah organisasi yang berhubungan positif dengan pekerjaannya (seperti antusiasme, berenergi, dan bersemangat) serta 
keterlibatan tersebut merupakan keadaan motivasi yang tercermin dalam kemauan tulus untuk menginvestasikan fokus karyawan pada tujuan dan kesuksesan organisasi (Albrecht, 2010).

Kepemimpinan memiliki peran penting dalam keberlangsungan perusahaan sekaligus kinerja individu di dalamnya dimana tujuan kepemimpinan adalah membantu mengembalikan, mempertahankan dan meningkatkan dorongan karyawan dalam pekerjaannya (Pace \& Faules, 2013). Dengan adanya peran kepemimpinan maka terciptanya persepsi karyawan terhadap gaya pemimpin dan kemampuan pemimpin dalam menjalankan kinerja dan pencapaian tujuan organisasi, sehingga karyawan dapat memberikan dukungan dengan melibatkan usaha karyawan dalam keberlangsungan organisasi (Kennedy dan Anderson, 2002: 546).

Pemimpin atau atasan dalam perusahaan memiliki gaya atau cara kerja (operating style) dalam berinteraksi dan berkomunikasi di dalam perusahaan. Reddin menjelaskan bahwa terdapat teori 3D yang menjelaskan gaya atasan dalam tingkat pengarahan atasan atas usaha karyawan untuk mencapai tujuan (orientasi-kerja), tingkat hubungan pribadi antara atasan dengan karyawan, ditandai oleh adanya saling mempercayai, menghormati gagasan dan memperhatikan perasaan karyawan (orientasi-hubungan), dan tingkat persyarataan produksi yang dicapai atasan yang telah ditetapkan (keefektifan) (Pace \& Faules, 2013: 283-284) .

Melalui orientasi-kerja, orientasi-hubungan dan keefektifan muncul empat gaya pemimpin efektif dan empat gaya pemimpin kurang efektif. Keempat gaya pemimpin lebih efektif yaitu, sebagai berikut pertama gaya Eksekutif (Executive) yakni mempunyai tugas berat, hubungan kuat, muncul sebagai motivator yang baik, yang memperlakukan setiap orang dengan cara tersendiri dan lebih suka melakukan manajemen tim. Kedua yaitu gaya Otokrat Lunak (Benevolent Autocrat) mempunyai tugas berat, hubungan lemah, tampak mengetahui apa yang diinginkannya dan tahu cara memperolehnya tanpa menimbulkan ketidaksenangan. Ketiga yaitu gaya Pengembangan (Developer). Mempunyai tugas ringan, hubungan kuat; tampak mempercayai orang lain secara terselubung dan menaruh perhatian utama pada pengembangan hubungan yang selaras. Keempat yaitu gaya Birokrat (Bureaucrat). Mempunyai tugas ringan, hubungan lemah; tampak menaruh perhatian pada aturan-aturan dan prosedur demi kepentingan mereka sendiri, dan karena ingin menjaga serta 
mengawasi situasi dengan menggunakan aturan dan prosedur itu, mereka sering terlihat amat berhati-hati (Pace \& Faules, 2013: 283).

Adapun empat gaya atasan kurang efektif yaitu pertama Pencari Kompromi

(Compromiser).

Mempunyai tugas berat, hubungan kuat, meskipun satu atau mungkin tidak ada satu pun yang sesuai; muncul sebagai pembuat keputusan yang buruk dan membiarkan tekanan amat mempengaruhinya; tampak lebih suka meminimalkan tekanan dan masalah daripada memaksimalkan produksi jangkapanjang. Kedua yaitu Otokrat (Autocrat), mempunyai tugas berat, hubungan lemah ketika perilaku tertentu tidak sesuai; tampak tidak mempunyai kepercayaan kepada orang lain, hanya tertarik pada tugastugas langsung. Ketiga Pembawa Misi (Missionary) yang mempunyai tugas ringan, hubungan kuat ketika perilaku tertentu tidak sesuai; tampak lebih tertarik kepada manusia sebagai pribadi. Keempat yaitu Penyendiri (Deserter) yang mempunyai tugas ringan, hubungan lemah ketika perilaku tertentu tidak sesuai; tampak seperti tidak terlibat dan pasif (Pace \& Faules, 2013: 284).

Reddin menjelaskan bahwa perbedaan mendasar antara gaya yang kurang efektif dan yang lebih efektif terletak pada kualitas seorang atasan. Kemudian keempat gaya yang lebih efektif memiliki potensial untuk sama-sama efektif, bergantung pada situasi yang dihadapi, karena ada saatnya ketika keempat gaya tersebut diperlakukan sekaligus, dan pada saat tertentu sebuah tugas memerlukan satu atau dua gaya secara teratur (Pace \& Faules, 2013: 283).

\section{METODOLOGI PENELITIAN}

Metodologi penelitian yang digunakan adalah kualitatif. Menurut Neuman (2014: 176), kualitatif adalah penelitian yang menggunakan bahasa kasus dan konteks, serta menggunakan bricolage (berbagai cara atau material), memeriksa proses dan kasus dalam konteks sosial mereka yang kemudian di interpretasi dari berbagai sudut pandang.

Pengumpulan data primer dilakukan dengan melakukan wawancara kepada narasumber yakni karyawan Soho Square Indonesia. Narasumber dari divisi Account Dessy Puspitasari (Account Director), Kayrana Amadyatara (Account Executive), kemudian dari divisi Creative Putri Savita (Graphic Designer) dan sekertaris perusahaan Anggi Kusuma Wardhani (Team Secretary).

Pengumpulan data sekunder menggunakan materi dan referensi 
dari penelitian sebelumnya, internet dan perpustakaan. Analisis penelitian dilakukan dengan menggunakan model Miles dan Huberman yang dilakukan dengan reduksi data, penyajian data dan kesimpulan.

\section{HASIL PENELITIAN DAN PEMBAHASAN}

Pelaksanaan

kegiatan

komunikasi internal dapat melalui berbagai kesempatan namun agar berjalan dengan efektif konten dapat disesuaikan dengan relevansi situasi dan waktu. Berikut uraian Kayrana Amadyatara (Account Executive Soho Square Indonesia):

"Komunikasi internal selalu terjadi di kantor, kita satu sama lain berinteraksi. Untuk waktu, saya percaya kapan pun terjadi, baik saat kita kerja ataupun di luar. Kontennya beragam. Kalau di waktu jam kerja sudah pasti topik pembicaraan berkisar di proyek tim kita, seperti intruksi untuk pertemuan internal dengan klien atau briefing, kalau situasi sedang lunch break saling berinteraksi saja, sekaligus makan bersama, terkadang masih terkait kerjaan namun lebih santai".

Dessy Puspitasari Account Director Soho Square menjelaskan:
"Menurut saya komunikasi internal berjalan setiap saat di dalam perusahaan, baik internal secara formal occasions ataupun informal occasions. Seperti mengobrol saat makan siang juga termasuk komunikasi internal, walaupun diluar konten kerjaan, saat seperti itu juga diperlukan untuk setiap karyawan. Kemudian konten menyesuaikan situasi, dalam kerjaan seputar update, follow up, crosscheck kerjaan, brief tugas atau arahan dari klien di luar jam kantor lebih bebas."

Pemanfaatan waktu dalam berkomunikasi membantu dalam menghasilkan komunikasi yang efektif kepada karyawan. Penyaluran konten yang disalurkan oleh atasan kepada bawahan (subordinate) juga harus dapat memengaruhi sekaligus membantu kinerja karyawan, seperti pernyataan Dessy Puspitasari (Account Director Soho Square Indonesia):

"Konten yang dapat membangun kinerja karyawan memerlukan isi yang dapat mereka terima, mengerti dan pahami. Jadi pemberian instruksi harus jelas. Kemudian kita sering melakukan diskusi ide dan masukan untuk proyek dan 
pada ujungnya keputusan diambil bersama-sama agar seluruh tim puas semua. Di luar kerjaan, komunikasi yang terjadi bisa dibaurkan konteks sesuai suasana, lebih santai. Interaksi ini selain berkomunikasi namun juga untuk mengenal dan mengerti sesama anggota tim".

Pernyataan Account Director sebagai atasan sesuai dengan pernyataan dari bawahan (subordinate) Account Executive (AE) Karyana sebagai berikut:

"Peran komunikasi internal sangat mempengaruhi kinerja kita, karena ranah $\mathrm{AE}$ di periklanan lebih kepada komunikasi, kemudian dengan komunikasi di dalam yang baik, proses kerja jadi lancar, seperti pemberian brief oleh Account Director, penjelasan instruksi untuk perihal photoshoot, dan brainstorming akan lebih jelas kalau dari awal komunikasi antar tim lancar. Yang sangat terlihat pentingnya, ketika decision making, kita harus diskusi dulu, kalau komunikasi tidak baik akan mempersulit saat pengambilan keputusan."

Berdasarkan hasil wawancara dengan informan dapat diketahui bahwa dalam pekerjaannya, anggota Soho Square, terutama divisi Account selalu memiliki hubungan komunikasi yang baik di dalam ataupun di luar jam kerja. Komunikasi internal berperan penting digunakan dalam pertukaran pesan serta informasi dalam kelancaran proses dan hasil kerja mereka.

Pemilihan saluran dan media komunikasi yang sesuai adalah penting dalam kelancaran proses kerja karyawan. Komunikasi langsung (direct communication) seperti face to face dan komunikasi tidak langsung (indirect communication) memiliki kegunaanya masing-masing dalam berjalanan komunikasi internal dalam perusahaan.

Dessy Puspitasari Account Director Soho Square menjelaskan:

"Biasanya komunikasi internal secara langsung. Kita juga menggunakan email khusus untuk menyebarkan informasi ke anggota tim. Kalau tim Account saya memiliki group chat di WhatsApp. Jadi, baik langsung maupun tidak langsung, keduanya digunakan. Tinggal menyesuaikan dengan kebutuhan dan situasi saat itu." 
Pernyataan Account Director sebagai atasan sesuai dengan pernyataan dari bawahan (subordinate) Account Executive Karyana sebagai berikut:

"Baik langsung maupun tidak langsung, keduanya dipakai sebagai media komunikasi kita. Seperti email, chatting, SMS digunakan sesuai kondisi."

Berdasarkan pernyataan para narasumber yakni kedua saluran, baik langsung maupun tidak langsung diperlukan dalam komunikasi yang digunakan saat pelaksanaan kerja mereka seharihari. Keduanya, atasan dan bawahan (subordinate) menyadari penggunaan dan pemanfaatan media yang dipilih sebagai sarana komunikasi menyesuaikan situasi dan kondisi.

Dessy selaku Account Director mengatakan yang dilakukan saat berkomunikasi dengan bawahannya:

"Secara pribadi, saya lebih suka bertemu, tatap muka, karena bisa langsung di respon apabila ada pertanyaan atau saran dari karyawan dan lebih optimal terlebih lagi ketika ada perbedaan ide saat brainstorming lebih mudah langsung bicara. Namun, kalau kondisi ranah kita, biasanya kerjaan ada dari klien yang biasanya di salurkan ke tim melalui email jadi pembicaraannya dilanjutkan di email atau terkadang juga menggunakan WhatsApp, baik personal atau group chat"

Penyesuaian penggunaan saluran dan media tersebut berguna bagi karyawan untuk melaksanakan tugas dan proyek yang dilakukan. Berdasarkan keefektifitasan, Kayrana selaku Account Executive mengatakan:

"Kalau lebih efektif, Face to Face ya, karena kalau email, kan dibaca tapi interpretasi orang bisa berbeda. Tapi kalau Face two Face terkadang ada time constrain, timeline, segala macam, khususnya susah juga kalau yang diajak bicara diluar, jadi kita menggunakan email, WhatsApp atau hubungi langsung via telepon untuk saling komunikasi."

Berdasarkan pernyataan tersebut, penggunaan media komunikasi di pertimbangkan dari keefektivitasan media tersebut dalam kondisi tertentu. Atasan di Soho Square memilih komunikasi langsung atau face to face karena jawaban atau balasan dari penerima pesan dapat langsung di terima sekaligus tanggapi, khususnya dalam situasi berdiskusi. Sedangkan bawahan atau subordinate lebih 
menitik beratkan kepada interpretasi pesan yang dapat diterima berbeda oleh penerima apabila melalui indirect communication seperti email dan group chat.

Menciptakan proses komunikasi internal yang dapat berlangsung efektif salah satunya dengan peran dan gaya pemimpin berkomunikasi. Gaya komunikasi atasan di Soho Square Indonesia mengutamakan open communication dengan tujuan untuk membuat karyawan aktif dalam penyampaian opini dan ide seperti yang dijelaskan oleh Dessy Account Director:

"Saya memilih untuk berkomunikasi dengan casual dengan motto space to speak karena ranah kita di periklanan cukup tegang oleh tuntutan klien, jadi untuk menjaga kondisi saat kita kerja dan membuat karyawan tetap nyaman dengan kerjaannya jadi dipandunya secara santai."menurut penjelasan yang diberikan Dessy.

Kayrana sebagai bawahan Dessy di dalam divisi Account berpendapat:

"Komunikasi di kantor santai dan seperti teman dengan atasan yang interaksinya secara casual. Jadi leluasa untuk bertanya dan berpendapat. Kemudian di saat banyak kerjaan dan out of hands, atasan tidak segan untuk membantu."

Hal ini dibenarkan oleh Putri selaku Graphic Designer Soho Square, yakni:

"Kalau di tim Account, khususnya para Account Directors, mereka semua flexible, ya, jadi tidak tegang begitu atmosfer di ruangan, juga, kalau di SOHO saling terbuka komunikasinya, jadi kalau ingin beropini, ya open space begitu, bahkan diencourage oleh mereka untuk berpendapat. Walaupun tidak terelakkan kalau sedang ada projek pitching, terkadang cukup tegang karena hectic, ya, tapi mereka cepat kembali normalnya, begitu, karena kalau di lanjutin moody nya juga tidak membantu selesaikan projeknya."

Berdasarkan pernyataan informan, penggunaan gaya komunikasi atasan yang membebaskan karyawan untuk berpendapat dan beropini dapat menciptakan lingkungan yang nyaman di Soho Square Indonesia dan membantu kinerja mereka dalam berkerja.

Dalam proses komunikasi internal yang efektif, diperlukannya keyakinan bawahan (subordinate) 
terhadap atasannya yang dapat dilihat melalui keselarasan aksi dan perkataan oleh atasan dalam lingkungan kerja. Kayrana selaku Account Executive menjelaskan:

"Pemberian tugas bukan seperti 'perintah' dan kita kerjakan sama persis dengan cara atasan bertindak dalam tugas tersebut, tapi atasan memberikan kebebasan untuk kita melakukan apa yang kita dapat lakukan yang penting output sesuai dengan target. Jadi kita dapat memperluas pengalaman."

Hal tersebut sesuai dengan pernyataan yang di sampaikan oleh Dessy Account Director sebagai atasan Kayrana:

"Saya memberikan instruksi kepada subordinate saya bukan berarti membuat mereka bekerja mengikuti cara saya bekerja. Saya lebih ke result oriented, contohnya saya berikan tugas dengan jelas untuk mendapatkatkan nilai 10 , saya memberikan keleluasaan bagaimana cara mereka sampai angka 10, baik $5+5,7+3,8+2$, yang penting menghasilkan angka 10. Agar mereka dapat mencari cara dan kembali lagi, memberikan pengalaman kerja,"
Konsistensi antara gaya komunikasi yang sekaligus sebagai gaya penyampaian informasi dan pemberian tugas membuat karyawan di Soho Square Indonesia bekerja maksimal dan masing-masing memiliki kepercayaan dan kredibilitas atasan diakui.

Pelaksanaan kinerja di dalam perusahaan dapat terjadi kesulitan dalam pengerjaannya. Apabila bawahan (subordinate) memiliki kesulitan dalam pekerjaan hingga menghasilkan permasalahan, keberadaan atasan terlihat saat memberi bantuan untuk karyawannya.

Dessy Puspitasari Account Director Soho Square menjelaskan:

"Ada saatnya saya memulai komunikasi, namun saya juga memberi kesempatan mereka untuk aktif, khususnya dalam proyek mereka. Saya akan turun ke lapangan terutama saat terdapat urgent situation yang berhubungan dengan individu di internal yang memiliki level diatas mereka (subordinate), maka saya yang memulai interaksinya. Kemudian situasi dimana subordinate saya sudah memiliki beban kerja yang banyak, apabila ingin mengkomunikasikan ke atas, seperti Managing Director maka saya yang menyuarakan dan bargaining untuk 
memberikan beberapa proyek ke tim yang lain, jadi dapat meringankan sekaligus memaksimalkan fokus kerja tim saya."

Kayrana sebagai bawahan Dessy di dalam divisi Account menambahkan:

"Ketika ada tugas yang tidak bisa saya atasi atau menjadi masalah yang saya ragu mampu selesaikan, saya dapat langsung berdiskusi dengan Account Director dan tim untuk mencari jalan keluar bersama."

Menurut Putri Savita selaku Graphic Designer menjelaskan:

"Kalau ada kesalahan kecil, seperti salah tulis warna di job request masih bisa di tangani oleh Account Executive, tapi kalau sudah menyangkut klien atau Production House, Account Director langsung turun ke lapangan, ya. Karena sejauh yang saya lihat, atasan di Soho Square itu aktif dalam meninjau kerjaan subordinate mereka, jadi saling mengontrol, saja. Ada disaat saya menyaksikan Account Director (Dessy) itu memberitahu secara tegas ke salah salah satu karyawannya dan mereka akan mencari jalan keluar bersama, karena atasan di sini tidak sungkan untuk maju saat masalah terjadi."

Peran atasan dalam mengontrol serta menyelesaikan permasalahan yang terjadi di Soho Square Indonesia dilakukan secara aktif dan tegas, memperlihatkan penggunaan komunikasi dengan baik yang disesuaikan dengan situasi.

Dalam lingkungan kerja untuk menciptakan keterlibatan karyawan dalam kegiatan perusahaan diperlukannya pengakuan usaha dan eksistensi karyawan dan ruang mereka dalam berpendapat.

Berikut penjelasan Dessy sebagai Account Director sekaligus atasan di tim Account:

"Saya memberikan keleluasaan bagi karyawan untuk mengutarakan opini dan ide-ide mereka, agar keputusan yang dibuat lebih bagus dan karyawan ada kontribusi saat proyek di release. Terlebih lagi, karena saya ingin mereka memiliki kemampuan dalam problem solution yang saya percaya sangat berguna berkembang dan untuk karir mereka kedepan. Hal ini penting, karena jika tidak adanya ruang untuk mereka, maka mereka akan bergantung dengan saya dan sebagai 
Account Executive yang sangat penting adalah mencari jalan keluar untuk situasi atau kendala yang terjadi yang kemudian samasama kita saling bertukar ide dan solusi."

Menurut Kayrana sebagai Account Executive dan bawahan mengatakan:

"Untuk inisiatif disini terbuka, bahkan ketika tukar pendapat dalam sebuah keputusan, karyawan di dorong untuk aktif memberi masukan-masukan dan ide kreatif, terutama saat sesi problem solution. Jadi ada kontribusi kita dalam proyek."

Usaha dan eksistensi karyawan menghasilkan potensial kesuksesan dalam projek yang mereka ikut berkontribusi. Dalam hal ini atasan di Soho Square memberikan apresiasi dan pengakuan terhadap bawahan (subordinate) di mana Dessy menjelaskan:

"Pengakuan atau apresiasi ialah dengan 'Giving them feedback' dimana atasan memberikan sesi private yang membahas kinerja karyawan sekaligus pujian dan dorongan untuk menjaga kualitas kerja mereka. Perayaan seperti makan bersama atau atasan men-traktir dan pemberian hadiah kepada karyawan juga

dilakukan pada acara tertentu. Juga, di dalam perusahaan sendiri, kita para level up employee, diberikan annual training mengenai "How to build relationship with your subordinate, yakni yang diadakan oleh WPP group"

Kayrana sebagai bawahan (subordinate) Dessy di dalam divisi Account berpendapat:

"Kalau atasan selalu kasih tahu ketika suatu proyek itu selesai kita diminta untuk ngblast hasil karya kita ke tim yang terlibat, supaya anggota itu tahu kerjaan kita itu apa baru disitu akan diberikan feedback nya misalnya, "Good job, kedepannya kita bisa tingkatkan" jadi termotivasi untuk terlibat di proyek-proyek seterusnya. Di kantor sendiri setiap enam bulan sekali atau setahu sekali diadakan Creative RoundUp, jadi WPP Ogilvy akan periksa kerjaan terbaik karyawannya dan ada hadiahnya. Walaupun biasanya lebih ke divisi kreatif, tapi Account juga diikutsertakan dari kontribusi membantu dalam ide dan halhal yang menghasilkan karya tersebut." 
Anggi sebagai Team

Secretary menambahkan:

"Soho Square dikenal memiliki atasan yang

mendukung 'anak-anak' nya untuk mengikutkan diri mereka dalam proses pengerjaan proyek dan untuk aktif di dalamnya. Apresiasi terlihat ketika atasan memuji dan memberi feedback atau makan-makan setelah performance mereka."

Berdasarkan pernyataan informan di atas terlihat bahwa apabila karyawan akan melibatkan dirinya dalam perusahaan melalui kinerja dan performa mereka salah satunya karena lingkungan yang mendorong sekaligus mengapresiasi usaha yang mereka lakukan.

Budaya komunikasi di Soho Square Indonesia adalah kekeluargaan. Hal ini dilihat dari interaksi dan kegiatan di luar waktu bekerja antara atasan dan karyawan. Atasan yang menyebut anggota tim sebagai 'anak-anak' nya serta memperlakukan mereka seperti teman yang dapat saling mengerti dan diajak berdiskusi, terlepas dengan keduanya, atasan dan bawahan menjaga profesionalisme pekerjaan masing-masing. Dessy menjelaskan:

"Soho Square Indonesia memiliki kantor yang terbilang kecil dengan jumlah pekerja 30 orang, jadi tidak memerlukan birokrasi tertentu. Kedua, kita itu kekeluargaan yang flexible dimana khususnya atasan bisa menempatkan dan menyesuaikan diri sebagai teman, kawan bagi karyawan, jadi feedback dari karyawan lebih sering, selama kewajiban profesi masih dilaksanakan."

Kayrana di tim Account menambahkan,

"Soho Square identik dengan kekeluargaan, dibandingkan dengan agensi-agensi di gedung yang sama, keakraban interaksi keluarga Soho Square memang menonjol. Setiap individu mudah berbaur, terutama para atasan yang menyambut kita dengan ajakan dan dorongan dalam pekerjaan sehari-hari."

Kegiatan dalam menjaga efektivitas penerapan budaya kekeluargaan di Soho Square Indonesia terlihat dengan kegiatankegiatan yang dibuat oleh kantor untuk menjaga keakraban dan kekompakan setiap tim di kantor.

Anggi selaku Team Secretary Soho Square menjelaskan:

"Kita sering adakan acaraacara internal potluck, trip ke 
luar, atau bahkan kalau sehari-hari kadang kita seruseruan outfit of the day samaan, mau warna apa misalnya. Juga kita sering adakan party dengan divisi atau agensi lainnya, kita biasanya kompak, beberapa kali kita menang performance dalam katagori kompetisi grup."

Berdasarkan penjelasan di atas, atasan di Soho Square berperan dalam menciptakan lingkungan kerja yang nyaman bagi karyawannya dengan menerapkan komunikasi atasan dengan bawahan seperti komunikasi dengan sesama teman. Karyawan merasa bahwa dengan perlakuan tersebut komunikasi dua arah (two ways communication) di kantor berjalan lancar dalam keseharian pekerjaan mereka.

Dalam proses komunikasi yakni pertukaran pesan dan informasi yang dilakukan oleh setiap karyawan di dalam perusahaan akan menghadapi kendala atau adanya kesenjangan (gap) antara posisi karyawan. Dalam komunikasi internal di Soho Square tidak adanya kesenjangan yang berarti antara posisi atau level pekerjaan. Hal ini disebabkan karena Soho Square Indonesia menerapkan open communication pada setiap karyawan. Dalam berkomunikasi dan berinteraksi dapat dilakukan ke siapa saja dalam kondisi saling menghormati satu sama lain.

Menurut penjelasan Dessy, kendala dalam berkomunikasi ketika:

"Komunikasi akan terhambat ketika workload (beban kerja) di setiap tim sudah banyak, jadi situasi hectic di kantor, dimana untuk mengkomunikasikan tugas baru jadi tidak enakkan. Jadi caranya saling pengertian, saya tanyakan prioritas proyek yang sedang dikerjakan bagaimana, baru tugas-tugas yang baru saya sampaikan via email, kalau tatap muka penjelasan jadi panjang sedangkan mereka sedang sibuk dengan deadlines jadi juga tidak mengganggu."

Kayrana menambahkan:

"Kalau proyek sedang menumpuk, kesulitan komunikasi untuk update atau report lumayan, apalagi kalau sedang pitching klien, cukup sensitif karena dikejar deadlines, jadi biasanya komunikasi tugas di pindah ke email dan atau post note di meja yang berkepentingan sebagai reminder, jadi saling sadar dengan situasi."

Putri selaku Graphic Designer Soho Square berpendapat:

"Dalam perihal kerja, hambatan lebih kepada saat situasi di kantor sedang penuh dengan proyek, dimana 
sering terjadi, khusunya di waktu-waktu sebelum acaraacara besar, seperti Ramadhan, Hari Kemerdekaan, Natal, sampai Tahun Baru, klien selalu persiapkan iklan-iklan, jadi lebih sering hectic kita di kantor. Di saat-saat itulah hambatan ada di waktu untuk mengkomunikasikan kerjaankerjaan yang menunggu."

Soho Square sebagai agensi advertising \& marketing communications memiliki berbagai klien lokal dan internasional, secara otomatis proyek-proyek iklan terutama saat sebelum menjelang hari besar nasional dan internasional atau ketika sedang ada pitching potensial klien, maka laju komunikasi internal untuk menginformasikan dan pelaporan tugas tertunda. Terlihat dari pernyataan narasumber bahwa cara yang digunakan dalam mengatasi hal ini adalah atasan berusaha mengerti kondisi karyawannya dengan menanyakan proyek mana yang diprioritaskan kemudian perkembangan proyek tersebut, kemudian tugas-tugas baru akan disalurkan melalui email agar tidak mengganggu fokus karyawan. Hal ini menunjukan bahwa atasan berusaha mengukur dan mempertimbangkan kondisi karyawan sebelum memberikan pekerjaan baru, dimana dengan melakukan hal tersebut komunikasi yang berjalan selanjutnya atau setelah proyek ditangani karyawan selesai, maka karyawan dapat menempatkan fokus mereka pada tugas baru selanjutnya.

Kegiatan komunikasi internal merupakan hal yang penting dalam organisasi (Farrant, 2003: 2). Deetz menambahkan bahwa komunikasi internal merupakan fenomena yang sekaligus menjadi hal yang dapat mendeskripsikan dan menjelaskan organisasi (Jablin \& Putnam, 2001: 5). Hal ini menjadikan pentingnya komunikasi sebagai media pusat penyalur informasi, menciptakan relasi, membuat karyawan saling mengerti dan membangun nilai dan budaya organisasi bersama-sama yang menjadikan organisasi dapat berkerja dalam sinkronasi yang baik antara karyawan-karyawannya (Berger, 2008).

Dalam menjelaskan dan pendalamaan temuan penelitian digunakan konsep Keterlibatan Karyawan (Employee Engagement) yang mengartikan saat karyawan terlibat dalam tugas-tugas dan tanggung jawab organisasi ialah saat timbulnya rasa inisiatif, adanya usaha dan persistensi yang menghasilkan kepuasan, antusianisme dan motivasi bagi karyawan itu sendiri dalam menjalankan rutinitas pekerjaannya di dalam organisasi (Albrecht, 2010) dimana dalam menjalankan 
pekerjaan, setiap karyawan membutuhkan komunikasi, baik ke atasan ataupun bawahan untuk melaksanakan dan menuntaskan tugas-tugasnya. Dalam bagian ini akan dibahas mengenai proses pelaksanaan komunikasi interal dari divisi Account Executive Soho Square Indonesia berdasarkan efektif komunikasi internal dari Bruce Berger (2008), yaitu terdiri dari ketepatan waktu dan konten (timeliness and content), saluran (channel), peran kepemimpinan (leadership roles), partisipasi dan pengakuan (participation and recognition), pengukuran (measurement), budaya (culture).

Berdasarkan hasil analisis dari wawancara mendalam dengan para informan di Soho Square Indonesia diketahui bahwa atasan di Soho Square Indonesia berusaha membangun hubungan komunikasi yang harmonis dengan karyawan di Soho Square dengan menerapkan efektif komunikasi internal yang sesuai dengan Bruce Berger (2008) bahwa untuk berlangsungnya sebuah perusahaan diperlukan komunikasi yang efektif antara atasan dan karyawan agar hubungan pada individu setiap level terkoneksi sehingga perusahaan dapat berjalan dengan baik.

Praktik komunikasi internal di Soho Square Indonesia berjalan menyesuaikan dengan waktu serta situasi pembicara, ketika jam kerja maka konten yang dibicarakan adalah mengenai proyek-proyek yang dikerjakan, sedangkan pada jam istirahat atau diluar jam kerja, para karyawan dan atasan saling berinteraksi membicarakan topiktopik ringan, menunjukkan konten yang dibawakan relevan dengan situasi. Hal ini sesuai dengan pernyataan Berger, bahwa pemberian informasi yang relevan dan tepat waktu kepada karyawan menjadi dasar kesuksesan komunikasi internal (2008). Kemudian dalam pelaksanaan komunikasi internal diketahui melalui wawancara bahwa di Soho Square Indonesia menggunakan dua saluran (channel) yaitu komunikasi secara langsung (direct communication) dan komunikasi tidak langsung (indirect communication) dengan memanfaatkan media elektronik dan internet seperti email dan group chat WhatsApp, di mana sebenarnya individu-individu di Soho Square Indonesia lebih memilih untuk berkomunikasi secara langsung sebab dipercaya lebih dapat menyampaikan pesan dan informasi secara lebih detail dan baik. Penggunaan media dalam komunikasi internal di Soho Square Indonesia sesuai dengan yang diuraikan oleh Daft and Lengel (Berger, 2008: 7) yakni, "Face to Face communication is the richest medium and optimal channel for communicating complex information 
or resolving conflicts, for example. Di mana berkomunikasi secara tatap muka adalah cara yang optimal terutama dalam pemberian informasi yang rumit atau pemecahan masalah di kantor.

Peran kepemimpinan atau atasan di Soho Square Indonesia menerapkan komunikasi yang mengutamakan interaktif karyawan dalam keterlibatan mereka dalam pekerjaan dan proyek perusahaan. Atasan memberikan ruang untuk karyawannya menyalurkan ide, opini dan pendapat termasuk keluhan dan kritik mengenai proyek yang dikerjakan karena atasan pecaya bahwa dengan keikutsertaan karyawan akan meningkatkan kualitas keputusan (decison making) dalam proyek-proyek iklan yang ditangani di perusahaan. Atasan di Soho Square terlihat dari wawancara memperlakukan karyawannya secara casual layaknya keluarga, dengan ajakan dan sebutan 'anak-anak' terhadap karyawan pada sesi wawancara, dimana atasan percaya dengan komunikasi yang casual dan kekeluargaan dapat membantu beban kerja karyawan agensi periklanan seperti Soho Square Indonesia dengan klien-klien besar namun hanya memiliki sumber daya manusia sebanyak tiga puluh orang dalam satu kantor. Sesuai dengan Pace \& Faules bahwa kepemimpinan memiliki posisi dalam membantu mempertahankan dan meningkatkan motivasi serta keterlibatan karyawan (Pace \& Faules, 2013: 276). Dimana Berger (2008) menguraikan keterkaitan peran atasan dalam komunikasi internal yang efektif, sebagai berikut:

"The communication style of leaders should invite-open, ongoing and transparent discussion so that people are willing to voice their opinions and suggestions."

Berger (2008) menyatakan dalam berkomunikasi internal yang efektif diperlukan keterbukaan dan keleluasaan untuk berdiskusi supaya karyawan bersedia untuk menyuarakan pikiran dan pendapatnya yang akan menciptakan hubungan yang efektif antara atasan dan bawahan.

Hal ini juga sesuai dengan model gaya kepemimpinan yang lebih efektif diuraikan oleh Reddin (dalam Pace \& Faules, 2013: 284), tepatnya pada tipe Eksekutif (Executive) bahwa atasan adalah orang yang melihat pekerjaannya secara efektif memaksimalkan upaya orang lain dalam hubungun dengan tugas jangka pendek dan panjang dimana atasan menetapkan standar tinggi untuk produksi dan kinerja dan mengakui bahwa karyawan memiliki perbedaan individu dan harapan (expectation) sehingga atasan memperlakukan setiap karyawan secara berbeda. 
Sesuai dengan kondisi di Soho Square Indonesia dengan beban kerja dari klien-klien yang banyak, namun atasan tetap menjaga hubungan kuat antara atasan dan karyawan sehingga gaya kepemimpinan ini efektif dalam mendorong karyawannya untuk partisipasi berinteraksi dan terlibat dalam pekerjaan dan optimalkan kondisi perusahaan.

Dengan beban kerja dari klien, performan karyawan dapat melalui kesulitan atau permasalahan.

Di Soho Square, atasan mengontrol serta menyelesaikan permasalahan yang terjadi di Soho Square Indonesia yang dilakukan secara aktif dan tegas, memperlihatkan penggunaan komunikasi dengan baik yang disesuaikan dengan situasi. Hal ini sesuai dengan uraian Berger (2008) bahwa dalam menciptakan komunikasi yang efektif di dalam perusahaan dibutuhkan peran atasan yang tampak dan memimpin di dalam interaksi internal kantor.

Soho Square Indonesia juga melihat perkembangan karyawannya serta mengakui dan mengapresiasi mereka yang berkontribusi dalam proyek-proyek perusahaan. Pengakuan dan apresiasi yang dilakukan oleh atasan terlihat ketika memberikan pujian serta perayaan seperti mentraktir tim makan dan memberikan hadiah pada acara tertentu. Namun yang sering dilakukan dalam mengapresiasi atasan terhadap karyawan di Soho Square Indonesia adalah pemberian feedback yang diketahui saat wawancara.

Pada sesi seminar dan training khusus disediakan oleh WPP kepada setiap level atasan (director) dimana atasan diajarkan memberikan sesi interaksi secara pribadi (seperti curhat) kepada karyawannya. Sesi interaksi memberikan pesan-pesan membangun dan meningkatkan potensi bawahan dimana akan menghasilkan performa maksimal karyawan.

Sesuai dengan uraian Berger yang menjelaskan bahwa adanya pengakuan atau apresiasi akan membantu membangun nilai-nilai dan identitas perusahaan sekaligus mencerminkan budaya khas perusahaan (Berger, 2008). Hal ini juga sesuai dengan laporan Gallup tahun 2008, 2010 dan 2012 bahwa salah satu pendorong keterlibatan karyawan tertinggi adalah dorongan dari atasan yang berupa pengakuan, pujian atau masukan (feedback) kepada karyawan (O'Nelll, et al, 2015: 4) .

Berdasarkan wawancara dengan para informan, Soho Square Indonesia dengan budaya khas kekeluargaannya yang sebagai ketertarikan dalam penelitian dimana budaya yang Soho Square miliki menciptakan komunikasi dua arah (two ways communication) antar individu-individu di perusahaan 
berjalan dengan efektif dan dapat di aplikasikan menyesuaikan kondisi beban kerja yang dimiliki karyawan dan situasi kantor yang terbilang kecil dibandingkan dengan kantorkantor agensi di gedung Sentral Senayan yang berada dalam naungan WPP Indonesia.

Hal tersebut sesuai dengan pernyataan Berger (2008) mengenai budaya dalam efektif komunikasi internal bahwa komunikasi dua arah yang berlanjut adalah fondasi untuk motivasi karyawan dan kesuksessan perusahaan, dimana komunikasi dua arah sekarang seluruh arah (every ways) menyediakan balasan (feedback) yang berkelanjutan, yang mana penting untuk dipelajari dan untuk proses perkembangan perusahaan karena dalam mencapai tujuan organisasi, komunikasi internal harus membantu menciptakan dan merefleksikan 'budaya untuk komunikasi' dimana karyawan pada setiap tingkat merasa bebas untuk secara terbuka berbagi ide-ide, opini dan pendapat. Hal ini akan menekankan pengertian karyawaan, membangun kepercayaan, menstimuli keterlibatan dan mendorong keberagam yang lebih besar (Berger, 2008)

Soho Square Indonesia juga menemukan kendala atau hambatan dalam komunikasi internal yang diterapkan melalui pengukuran (measurement) yang dilakukan oleh atasan dan karyawan di mana ranah kerja mereka di periklanan memberikan beban kerja yang tinggi dan menuntut waktu dan energi setiap tahunnya. Hal ini terjadi khususnya saat pitching proyek iklan dan pada hari-hari besar nasional di Indonesia, sehingga ditemukan hambatan komunikasi ketika kondisi kantor hectic dengan pitching dan pengerjaan proyek besar seperti proyek iklan di Hari Raya Ramadhan. Pada situasi tersebut pemberian tugas atau informasi terkait proyek klien lainnya akan sulit disalurkan secara pribadi, sehingga atasan dan karyawan memilih untuk menyampaikan melalui email.

Berger (2008) menyatakan bahwa pengukuran (measurement) adalah sebuah kunci untuk kesuksesan komunikasi di setiap perusahaan, melalui berbagai bentuk dan pendekatan, pengukuran membantu menentukan aksi dan tujuan yang tepat bagi perusahaan.

Selain itu, karyawan Soho Square dapat berkomunikasi dengan baik karena keyakinan karyawan terhadap kredibilitas atasan yang dapat dilihat melalui keselarasan aksi dan perkataan atasan didalam lingkungan kerja dimana sesuai dengan penyataan Berger (2008) bahwa seorang atasan harus menyelaraskan aksi dan katakatanya. Dengan kecocokan tersebut akan menjadikan atasan terpercaya oleh karyawannya, dimana 
komunikasi antara keduanya dapat berjalan efektif.

Hal ini membuat kegiatan komunikasi internal di Soho Square Indonesia cenderung mengikuti asumsi komunikasi internal efektif yang diuraikan oleh Bruce Berger dengan asumsi bahwa terbuka kepada karyawan pada setiap level komunikasi, saling memberikan ruang untuk menyalurkan ide, opini, pendapat serta kritik maka menghasilkan keefektifan komunikasi internal sekaligus mempertahankan kelangsungan perusahaan.

\section{SIMPULAN}

Kesimpulan yang dapat ditarik dari hasil penelitian ini adalah keberhasilan melaksanakan efektif komunikasi internal yang dilakukan Soho Square Indonesia, khususnya antara tim Account melalui open communication dan budaya kekeluargaan dalam menunjang dinamika kerja sebuah agensi periklanan.

Kegiatan komunikasi internal di Soho Square Indonesia dalam menciptakan keterlibatan karyawan dengan memberikan perintah dan intruksi sekaligus keleluasaan dalam bertanya dan berpendapat membantu karyawan untuk lebih berinisiatif dan aktif dalam pekerjaan. Komunikasi secara langsung (f-t-f) dan tidak langsung (email, group chat) dimanfaatkan sesuai situasi dan kondisi. Kegiatan outing atau trip lokal atau interlokal dilaksanakan Soho Square Indonesia setiap tahunnya sebagai bentuk kegiatan komunikasi internal yang bertujuan untuk mempererat individu di perusahaan. Karyawan dapat mengatasi kendala ketika project hectic dengan memprioritaskan project deadlines dan pemanfaatan media komunikasi seperti email, untuk briefing proyek atau update terbaru dari klien. Seluruh hal tersebut yang dimiliki Soho Square Indonesia mampu menjadikan berlangsungnya komunikasi internal secara efektif sehingga menjamin keberlangsungan perusahaan.

Rekomendasi bagi penelitian dengan topik serupa untuk dapat mengembangkan cakupan selain komunikasi internal dengan melakukan penelitian dalam aspek komunikasi organisasi lainnya seperti, komunikasi interpersonal, teknologi informasi dalam organisasi dan lainnya.

\section{UCAPAN TERIMA KASIH}

Terima kasih kami ucapkan kepada pihak Soho Square yang telah banyak membantu dalam proses pembuatan penelitian kami dan juga pihak LSPR atas dukungannya kepada kami. 


\section{DAFTAR PUSTAKA}

Albrecht, S. L. (2010). Handbook Of Employee Engagement.

Cheltenham: Edward Elgar Publishing Limited.

Barker, Larry L \& Deborah A. B (1993). Communication: Sixth Edition. New Jersey:

Prentice-Hall, Inc.

Berger, B. (2008).

Employee/organizational communications. Institute for Public Relations. Retrieved from: http://www. instituteforpr. org/topics/employeeorganization al-communications.

Gallup. (2013). Engagement at Work: Its Effect on Performance Continues in Tough Economic Times. Retrieved from Gallup.com: http://www.gallup.com/file/servi ce/

Gills, T. L. (2006). The IABC Handbook of Organizational. San Fransisco: Jossey-Bass.

Kalla, H. K. (2005). Integrated internal communications: a multidisciplinary perspective. Corporate Communications: An International Journal, 10(4), 302-314.

Kruse, K. (2012, June 22). What Is Employee Engagement. New York, Amerika. Retrieved from https://www.forbes.com/sites/ke vinkruse/2012/06/22/employeeengagement- what-and-why/ Lubis, M. (2017). Pertumbuhan Belanja Iklan 2016 Kembalo Normal. Indonesia. Retrieved from http://www.nielsen.com/id/en/pr ess-room/2017/PertumbuhanBelanja-Iklan-201 6-KembaliNormal.html Mackey, W. H., Schneider, B., Barbera, K. M., \& Young, S. A. (2009). Employee Engagement: Tools for Analysis, Practice, and Competitive Advantage. West Sussex: Wiley-Blackwell. McColl-Kennedy, J. R., \& Anderson, R. D. (2002). Impact of leadership style and emotions on subordinate performance. The Leadership Quarterly, 13(5), 545-559.

Neuman, W. Lawrence (2014).

Social Research Mthods:

Qualitative and Quantitative Approaches-Seventh Edition. England: Pearson Education Limited

O’Neill, K., Hodgson, S., \& Al Mazrouei, M. (2015). Employee engagement and internal communication: A United Arab Emirates study. Middle East Journal of Business Volume 10, 3-28.

Optimum Consulting. (2016). Oblog: Optimum Consulting. Retrieved from Optimum Consulting: 
ogroup.com.au/wp

content/uploads/2016/02/eBook-

Employee-Engagement.pdf.

Pace, R. W., \& Faules, D. F. (2013).

Komunikasi Organisasi Strategi

Meningkatkan Kinerja

Perusahaan. (D. Mulyana, Ed.)

Bandung, Indonesia: Remaja

Rosdakarya.

Ruliana, Poppy, Susi Andriani \&

Puji Lestari (2018). Internal

Communication Role in

Improving Performance of

Employees Hotel: Descriptive

Study at Employees Sari Ater

Hotel \& Resort in Ciater,

Subang Regency, West Java

Province. International Journal

of Engineering \& Technology

Volume 7, 259-261

Smith, L., \& Mounter, P. (2005).

Effective Internal

Communication. London: Kogan

Page Limited.

Welch, M. (2012). Appropriateness

and acceptability: Employee

perspectives of internal

communication. Public

Relations Review, 38(2), 246-

254.

Theaker, A. (2004). The Public

Relations Handbook. Routledge 